\title{
A RELATIVIZAÇÃO DA COISA JULGADA INCONSTITUCIONAL: UMA ANÁLISE ACERCA DO SEU CABIMENTO FRENTE AOS PRINCÍPIOS DA INTANGIBILIDADE E DA SEGURANÇA JURÍDICA
}

\author{
THE RELATIVIZATION OF RES JUDICATA UNCONSTITUTIONAL: AN \\ ANALYSIS ABOUT ITS APPROPRIATENESS AGAINST THE PRINCIPLES OF \\ LEGAL CERTAINTY AND INTANGIBILITY.
}

\begin{abstract}
TAIELE BALARDIN DE OLIVEIRA Bacharel em Direito pela Universidade Luterana do Brasil - ULBRA, campus Cachoeira do Sul
\end{abstract}

\section{RESUMO}

A relativização da coisa julgada inconstitucional é o instrumento pelo qual os doutrinadores visam à desconstituição da coisa julgada material, quando a sentença, já transitada em julgado, tenha sido fundamentada em lei que, posteriormente, foi declarada inconstitucional pelo Supremo Tribunal Federal. Por ser meio atípico de desconsideração da coisa julgada, a teoria deve ser analisada, sobretudo no que tange a sua adequação com a ordem processual e constitucional. 0 presente artigo tem como objetivo analisar o tema sob o enfoque de seu cabimento frente aos princípios da intangibilidade e da segurança jurídica. Para a sua construção foram utilizados 0 método de abordagem dedutivo e os métodos de procedimento monográfico e comparativo. Com a pesquisa foi verificada a grande controvérsia doutrinária sobre o tema e a necessidade de utilização da ponderação para a solução da questão debatida.

Palavras-chave: Coisa Julgada. Direito Constitucional. Direito Processual Civil. Inconstitucionalidade. Relativização.

\begin{abstract}
The relativization of res judicata unconstitutional is the instrument by which scholars seek to deconstitution of res judicata when the sentence has become res judicata, has been grounded in law was later declared unconstitutional by the Supreme Court. Because it means atypical disregard of res judicata, the theory must be considered, especially regarding their suitability with the procedural and constitutional. This article aims to analyze the issue from the standpoint of their appropriateness against the principles of inviolability and legal certainty. For its construction were used the method of deductive approach and methods of procedure and comparative monograph. With research was found the great doctrinal controversy on the issue and the need to use the weighting for the solution of the issue debated.
\end{abstract}

Keywords: Res Judicata. Constitutional Right. Civil Procedural Law. Unconstitutionality. Relativization.

\section{SUMÁRIO}

INTRODUÇAO; 1 ASPECTOS GERAIS DA COISA JULGADA E OS PRINCÍPIOS DA INTANGIBILIDADE E DA SEGURANÇA JURÍDICA; 2 OS INSTRUMENTOS UTILIZADOS PARA DESCONSTITUIÇÃO DA COISA JULGADA NO PROCESSO CIVIL BRASILEIRO; 2.1 Ação Rescisória; 2.2 Ação declaratória de nulidade ou querela nullitatis; 2.3 Denúncia por violação à Convenção Americana de Direitos Humanos; 3 OS CONTROLES JURISDICIONAIS DE CONSTITUCIONALIDADE NO ORDENAMENTO JURÍDICO BRASILEIRO; 3.1 Controle difuso; 3.2 Controle concentrado; 4 A TEORIA DA RELATIVIZAÇÃO DA COISA JULGADA INCONSTITUCIONAL; CONCLUSÃO; REFERÊNCIAS. 


\section{INTRODUÇÃO}

Para evitar o prolongamento ilimitado das demandas judiciais, o sistema normativo brasileiro prevê um termo final para o processo, que será o trânsito em julgado da decisão. Nessa senda, tem-se que o instituto da coisa julgada material é a garantia à intangibilidade das sentenças transitadas em julgado, constituindo-se no princípio da segurança jurídica.

Entretanto, muito embora a imprescindibilidade de um sistema que garanta a imutabilidade das decisões judiciais, como forma de propiciar à população segurança jurídica, há falar de hipóteses em que a sentença, já acobertada pelo manto da coisa julgada material, foi prolatada com fundamento em aplicação de lei posteriormente declarada inconstitucional pelo Supremo Tribunal Federal.

A pesquisa surge, por conseguinte, em razão da necessidade de se analisar a possibilidade da aplicação de uma tese que permita que as sentenças judiciais transitadas em julgado, embasadas, todavia, em aplicação de lei considerada, posteriormente, inconstitucional pela Suprema Corte, possam ser revistas a qualquer tempo, ainda que escoado o prazo para interposição de ação rescisória, para que, então, se coadunem aos preceitos constitucionais.

O objetivo geral do trabalho será analisar a possibilidade da retroatividade da decisão do Supremo Tribunal Federal que declarou a inconstitucionalidade de lei que fundamentou sentença já transitada em julgado, após o prazo para ajuizamento da ação rescisória, relativizando a coisa julgada material já operada, frente aos princípios da intangibilidade e da segurança jurídica, após a promulgação da Constituição da República Federativa do Brasil de 1988, considerando a legislação processual civil e constitucional vigentes.

Como objetivos específicos buscar-se-á definir no que consiste a coisa julgada formal e material, levando-se em consideração a legislação constitucional e processual civil brasileira, ressaltando os princípios da intangibilidade e da segurança jurídica, analisar os aspectos gerais dos instrumentos utilizados para desconstituir a coisa julgada civil, descrever os controles jurisdicionais de constitucionalidade adotados no Brasil, averiguando os efeitos da decisão do Supremo Tribunal Federal nas ações diretas de inconstitucionalidade, bem como da resolução editada pelo Senado Federal, suspendendo a execução da lei declarada inconstitucional pela Suprema Corte na via do controle difuso e, por fim, verificar se a sentença, já acobertada pela coisa julgada material, deve subsistir, ainda que proferida com base em aplicação de lei que, 
depois de escoado o prazo para ajuizamento da ação rescisória, foi declarada inconstitucional pelo Supremo Tribunal Federal.

A pesquisa adotará o método de abordagem dedutivo, pois, a partir de uma análise geral a respeito da coisa julgada material e dos princípios da intangibilidade e da segurança jurídica, pretende-se chegar a uma conclusão acerca da possibilidade de retroatividade da decisão de inconstitucionalidade pelo Supremo Tribunal Federal, afetando a coisa julgada e a relativizando.

0 estudo também será pautado nos métodos de procedimento monográfico e comparativo. O método monográfico será empregado para proceder-se à conceituação dos institutos sopesados, bem como para se analisar as teses doutrinárias e jurisprudenciais que embasam o estudo da (im) possibilidade de relativização da coisa julgada inconstitucional. Por sua vez, o método comparativo será utilizado no confronto das teses levantadas pelo método monográfico, para chegar-se a uma conclusão acerca do tema.

A distribuição dos capítulos ocorreu na forma realizada, uma vez que não haveria como, inicialmente, falar acerca da teoria da relativização da coisa julgada inconstitucional, com suas divergências doutrinárias, sem analisar a importância da coisa julgada para o ordenamento jurídico, proporcionando a intangibilidade do julgado e a consequente segurança jurídica, assim como sem antes discorrer acerca dos instrumentos típicos e dos de construção doutrinária comumente aceitos para a revisão da coisa julgada, analisando-se as hipóteses de cabimento dos mecanismos.

Também não seria possível a abordagem do tema sem discorrer acerca do sistema de controle jurisdicional de constitucionalidade adotado no Brasil, fazendo-se um estudo acerca dos efeitos das decisões de inconstitucionalidade das leis.

Dessa forma, no primeiro capítulo serão abordados os aspectos gerais da coisa julgada, assim como os princípios que a amparam: a intangibilidade e a segurança jurídica.

No segundo capítulo se buscará analisar os instrumentos já existentes utilizados para desconstituir a coisa julgada, sendo estes: a ação rescisória, a ação declaratória de nulidade ou querela nullitatis e, por fim, a denúncia por violação à convenção americana de direitos humanos.

No terceiro capítulo serão examinados os controles jurisdicionais de constitucionalidade previstos no ordenamento jurídico brasileiro - controle concentrado e controle difuso -, observando-se os efeitos da declaração de inconstitucionalidade proferida pelo Supremo Tribunal Federal nos controles difuso e concentrado. 
Por fim, no quarto capítulo será conceituada a teoria da relativização da coisa julgada inconstitucional e serão demonstrados os argumentos doutrinários que defendem a sua aplicação no ordenamento jurídico, bem como aqueles contrários à sua utilização.

\section{ASPECTOS GERAIS DA COISA JULGADA E OS PRINCÍPIOS DA INTANGIBILIDADE E DA SEGURANÇA JURÍDICA}

A coisa julgada é o meio pelo qual se tornam intangíveis as controvérsias submetidas à apreciação do Poder Judiciário, de modo a garantir aos jurisdicionados segurança jurídica, mormente pelo fato desta trazer consigo, "inclusive como forma de se assegurar o resultado prático e concreto do processo, o impedimento à rediscussão do que foi (ou do que poderia ter sido) discutido na fase cognitiva". 1

Com previsão constitucional no rol das Cláusulas Pétreas do artigo $5^{\circ}$, XXXVI, da Constituição da República, ${ }^{2}$ assim como pautada pelas normas infraconstitucionais, consoante definição do artigo $6^{\circ}$, § $3^{\circ}$, da Lei de Introdução às Normas do Direito Brasileiro ${ }^{3}$ e do artigo 467 do Código de Processo Civil, ${ }^{4}$ o legislador erigiu a coisa julgada à norma essencial para o ordenamento jurídico, porquanto, pelo fato de imputar imutável o conteúdo da sentença, torna a prestação jurisdicional estável, constituindo-se no ápice da segurança jurídica.

No direito pátrio existem duas espécies de coisa julgada: a formal e a material, que se distinguem pelo âmbito em que atuarão para tornar a decisão intangível.

A coisa julgada formal é constituída pela impossibilidade de interposição de recurso contra a sentença, em razão da inércia da parte interessada no prazo plausível, ou porque

\footnotetext{
${ }^{1}$ GRINOVER, Ada Pellegrini. O processo: estudos e pareceres. São Paulo: Perfil, 2005, p. 114.

${ }^{2} \mathrm{CR}$ - Art. $5^{\circ}, \mathrm{XXXVI}$. A lei não prejudicará o direito adquirido, o ato jurídico perfeito e a coisa julgada. (BRASIL. Constituição da República Federativa do Brasil. Brasília: Senado Federal, 1988. Disponível em: <http://www.planalto.gov.br/ccivil_03/Constituicao/Constituicao.htm>. Acesso em: 20 dez. 2012).

${ }^{3}$ LINDB - Art. $6^{\circ}$, $\$ 3^{\circ}$. Chama-se coisa julgada ou caso julgado a decisão judicial de que já não caiba recurso. (BRASIL. Lei de Introdução às Normas do Direito Brasileiro. Rio de Janeiro: Congresso Nacional, 1942. Disponível em: <http://www.planalto.gov.br/ccivil_03/decreto-lei/Del4657compilado.htm>. Acesso em: 20 dez. 2012).

${ }^{4}$ CPC - Art. 467. Denomina-se coisa julgada material a eficácia, que torna imutável e indiscutível a sentença, não mais sujeita a recurso ordinário ou extraordinário. (BRASIL. Código de Processo Civil. Brasília: Congresso Nacional, 1973. 1 Disponível <http://www.planalto.gov.br/ccivil_03/Leis/L5869.htm>. Acesso em: 20 dez. 2012).
} 
esgotadas as vias cabíveis. Afirma-se doutrinariamente, portanto, que houve a "preclusão máxima"5 no processo em que estabelecida a controvérsia, tendo o feito transitado em julgado.

Sobrevindo a coisa julgada formal, tem-se que, em determinados casos, haverá, igualmente, a coisa julgada material, sendo esta última o ponto relevante no estudo da coisa julgada inconstitucional para a abordagem acerca de sua relativização, tendo em vista que, em razão de suas características, é essa que se visa proteger.

A coisa julgada material, diferentemente da formal, não está limitada apenas ao processo em que proferida a sentença, pois ultrapassa os limites deste, impedindo que seja manejada nova ação inter partes, idêntica àquela anteriormente ajuizada e já decidida.

É cediço que, para que a decisão judicial reste acobertada pelo manto da coisa julgada material, é necessário que sejam preenchidas determinadas condições.

A primeira está prevista legalmente no já mencionado artigo 467 do Código de Processo Civil, que refere ser a coisa julgada material a eficácia que torna imutável e indiscutível a sentença, não mais sujeita a recurso ordinário ou extraordinário. Portanto, percebe-se que o texto legal refere que haverá coisa julgada material se houver, primeiramente, a coisa julgada formal. ${ }^{6}$ Entretanto, além desta, Fredie Didier Junior, Paula Sarno Braga e Rafael Oliveira assinalam que devem estar presentes outras três:

a) há de ser uma decisão jurisdicional (a coisa julgada é característica exclusiva dessa espécie de ato estatal); b) o provimento há que versar sobre o mérito da causa (objeto litigioso); c) o mérito deve ter sido analisado em cognição exauriente $[\ldots]^{7}$

Assim, depreende-se que as sentenças somente alcançarão a coisa julgada material se preenchidos tais pressupostos, pois o fato de ter sido prolatada uma sentença, da qual houve preclusão para interposição do recurso cabível, não traz, irrefletidamente, a ocorrência da coisa julgada material.

\footnotetext{
${ }^{5}$ Adotam essa expressão: CINTRA, Antonio Carlos de Araújo; DINAMARCO, Cândido Rangel; GRINOVER, Ada Pellegrini. Teoria geral do processo. 25. ed. São Paulo: Malheiros, 2009, p. 328; MARINONI, Luiz Guilherme; ARENHART, Sérgio Cruz. Processo de conhecimento. 7. ed. rev. e atual. São Paulo: Revista dos Tribunais, 2008, p. 643; NEVES, Daniel Amorim Assumpção. Manual de direito processual civil. 4. ed. rev., atual. e ampl. São Paulo: Método, 2012, p. 532; DIDIER JUNIOR, Fredie; BRAGA, Paula Sarno; OLIVEIRA, Rafael. Curso de direito processual civil. 3. ed. Bahia: Juspodivm, 2008, p. 553.

${ }^{6}$ Como se nota, a coisa julgada material depende da coisa julgada formal, mas o inverso não acontece. (NEVES, Daniel Amorim Assumpção, op. cit., p. 532).

${ }^{7}$ DIDIER JUNIOR, Fredie; BRAGA, Paula Sarno; OLIVEIRA, op. cit., p. 553.
} 
Quanto à natureza jurídica desse instituto, verifica-se na doutrina grande dissenso no que tange ao fato de ser a coisa julgada material uma qualidade, uma situação jurídica, ou um efeito da sentença.

A doutrina majoritária segue o entendimento de Enrico Tulio Liebman, que sustenta ser a coisa julgada uma qualidade da sentença, ${ }^{8}$ sendo a definitividade, dessa forma, um atributo inerente desse instituto.

Para José Carlos Barbosa Moreira, apoiado pela doutrina de Alexandre de Freitas Câmara, Didier Junior, Braga e Oliveira, ${ }^{9}$ a coisa julgada é uma situação jurídica que surge quando a decisão não é mais passível de impugnação via recursal, tornando imutável a própria sentença e não os seus efeitos. Assim, leciona o doutrinador que

em determinado instante, pois, a sentença experimenta notável modificação em sua condição jurídica: de mutável que era, faz-se imutável - e porque imutável, faz-se indiscutível, já que não teria sentido nova discussão daquilo que não se pode mudar. ${ }^{10}$

Por fim, a terceira e última corrente dispõe ser a coisa julgada o efeito declaratório da sentença. Francisco Cavalcanti Pontes de Miranda, em obra atualizada por Sérgio Bermudes, elucida que

a coisa julgada material já é efeito. Não se diga que a coisa julgada material consiste na imutabilidade do ato processual; o ato processual é imutável, porque houve a coisa julgada, a vera sententia. [...] A imutabilidade que caracteriza a coisa julgada material é efeito atribuído à coisa julgada. ${ }^{11}$

Seguindo esses ensinamentos, defende a tese, entre outros, Luiz Guilherme Marinoni e Sérgio Cruz Arenhart, ${ }^{12}$ que a intangibilidade incide nos efeitos declaratórios que todas as

\footnotetext{
${ }^{8}$ Nesse sentido: NERY JUNIOR, Nelson. Princípios do processo civil na Constituição Federal. 8. ed. rev., ampl. e atual. São Paulo: Revista dos Tribunais, 2004, p. 38; NEVES, Daniel Amorim Assumpção, op. cit., p. 533; CINTRA, Antonio Carlos de Araújo; DINAMARCO, Cândido Rangel; GRINOVER, Ada Pellegrini, op. cit., p. 329; BULOS, Uadi Lammêgo. Curso de direito constitucional. 2. ed. rev. e atual. São Paulo: Saraiva, 2008, p. 492.

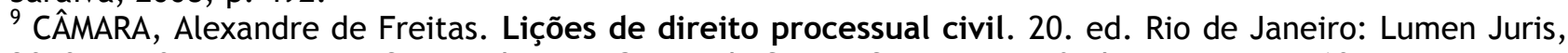
2010, p. 494; DIDIER JUNIOR, Fredie; BRAGA, Paula Sarno; OLIVEIRA, Rafael, op. cit., p. 560.

${ }^{10}$ MOREIRA, José Carlos Barbosa. Coisa julgada e declaração. São Paulo: Saraiva, 1977, p. 107-110. Apud: DIDIER JUNIOR, Fredie; BRAGA, Paula Sarno; OLIVEIRA, Rafael, op. cit., p. 559.

${ }_{11}$ MIRANDA, Francisco Cavalcanti Pontes de. Comentários ao Código de Processo Civil. Atualização legislativa de Sérgio Bermudes. vol. V. 3. ed. Rio de Janeiro: Forense, 1997, p. 108.

${ }^{12}$ MARINONI, Luiz Guilherme; ARENHART, Sérgio Cruz, op. cit., p. 648.
} 
sentenças possuem, ainda que não sejam sentenças declaratórias propriamente ditas, mas constitutivas, mandamentais, condenatórias ou executivas. ${ }^{13}$

Dessa forma, parece mais apropriada a tese que defende ser a coisa julgada uma situação jurídica advinda da imutabilidade da parte dispositiva da sentença, porquanto esta é que se tornará imutável após a ocorrência do trânsito em julgado.

Importante delinear os limites da coisa julgada, destacando-se os seus limites objetivos e subjetivos.

A coisa julgada restringe-se à matéria constante no decisum ou dispositivo da sentença, sendo esse o seu limite objetivo, não restando acobertados pela definitividade os motivos e fundamentos, ainda que determinantes para a decisão proferida, bem como a apreciação de questão prejudicial, decidida incidentalmente no processo, salvo se requerida pela parte, nos termos dos artigos $5^{\circ},{ }^{14} 325^{15}$ e $470^{16}$ do Código de Processo Civil.

Acerca dos seus limites subjetivos, depreende-se que a regra no direito positivo brasileiro, trazida pelo artigo 472 do Código de Processo Civil, ${ }^{17}$ é que a sentença faz coisa julgada inter partes, não atingindo terceiros, pois, admitindo-se que a coisa julgada torne imutável e indiscutível a sentença perante terceiros, estranhos à demanda já transitada em julgada, o ordenamento jurídico afrontaria os princípios constitucionais do contraditório, da ampla defesa e do acesso à justiça.

Assim, utilizando-se dos dizeres de Daniel Amorim Assumpção Neves, "a par das discussões doutrinárias a respeito do conceito de parte, entende-se que a coisa julgada vincula o

\footnotetext{
13 Utilizou-se a classificação das sentenças ensinada por Pontes de Miranda. (MIRANDA, Francisco Cavalcanti Pontes de, op. cit., Comentários ao Código [...], 1997, p. 39-49).

${ }^{14} \mathrm{CPC}$ - Art. $5^{\circ}$. Se, no curso do processo, se tornar litigiosa relação jurídica de cuja existência ou inexistência depender o julgamento da lide, qualquer das partes poderá requerer que o juiz a declare por sentença. (BRASIL, op. cit., Código de Processo Civil).

${ }^{15}$ CPC - Art. 325. Contestando o réu o direito que constitui fundamento do pedido, o autor poderá requerer, no prazo de 10 (dez) dias, que sobre ele o juiz profira sentença incidente, se da declaração da existência ou da inexistência do direito depender, no todo ou em parte, o julgamento da lide (art. $5^{\circ}$ ). (Ibidem).

${ }^{16}$ CPC - Art. 470. Faz, todavia, coisa julgada a resolução da questão prejudicial, se a parte o requerer (artigos $5^{\circ}$ e 325 ), o juiz for competente em razão da matéria e constituir pressuposto, necessário para o julgamento da lide. (Ibidem).

${ }_{17}$ CPC - Art. 472. A sentença faz coisa julgada às partes entre as quais é dada, não beneficiando, nem prejudicando terceiros. Nas causas relativas ao estado de pessoa, se houverem sido citados no processo, em litisconsórcio necessário, todos os interessados, a sentença produz coisa julgada em relação a terceiros. (Ibidem).
} 
autor, réu e terceiros intervenientes, à exceção do assistente simples, que suporta a eficácia da intervenção prevista pelo art. 55 do Código de Processo Civil”. 18-19

A exceção nos limites subjetivos da coisa julgada se configura quando esta se opera ultra partes ou erga omnes.

A coisa julgada ultra partes ocorre quando terceiros, estranhos à relação processual, são atingidos pela imutabilidade da sentença. É o que acontece com os sucessores e substitutos processuais que, muito embora não tenham feito parte do trâmite processual, passaram a ser titulares do direito controvertido no processo judicial.

Já nas demandas coletivas ou naquelas destinadas à tutela dos direitos individuais homogêneos, como, por exemplo, a ação popular, a ação civil pública e a prevista para proteção aos direitos dos consumidores, a coisa julgada poderá ser oponível contra todos.

Sobrevindo sentença que preenche os requisitos necessários para operar a coisa julgada material, considerar-se-ão concluídas e rechaçadas todas as possíveis arguições das partes, não realizadas durante o trâmite processual.

Logo, a coisa julgada material constitui verdadeiro óbice aos magistrados, já que não poderão se pronunciar, novamente, sobre questões já decididas, relativas à mesma lide. Ademais, manejada nova ação que tenha por objeto demanda idêntica, anteriormente ajuizada e já transitada em julgado, deve o magistrado extinguir o novo processo sem resolução de mérito, podendo fazê-lo, inclusive, de ofício.

Denota-se que esse instituto confere certeza jurídica aos casos já julgados, sendo imprescindível para a existência de um Estado Democrático de Direito, que visa e garante meios de pacificação jurídica e social, pois um ordenamento que resolve conflitos sem, contudo, garantir a imutabilidade do julgado, permitindo que os litígios já decididos se repitam ad infinitum, perpetra a incerteza e a angústia daqueles que esperam do judiciário a resposta para suas controvérsias.

O imperativo da intangibilidade da sentença transitada em julgado é justificado por Marinoni e Daniel Mitidiero, ao esclarecerem que

\footnotetext{
${ }^{18}$ NEVES, Daniel Amorim Assumpção, op. cit., p. 540.

${ }^{19}$ CPC - Art. 55. Transitada em julgado a sentença, na causa em que interveio o assistente, este não poderá, em processo posterior, discutir a justiça da decisão, salvo se alegar e provar que: I - pelo estado em que recebera o processo, ou pelas declarações e atos do assistido, fora impedido de produzir provas suscetíveis de influir na sentença; II - desconhecia a existência de alegações ou de provas, de que o assistido, por dolo ou culpa, não se valeu. (BRASIL, op. cit., Código de Processo Civil).
} 
não há Estado Constitucional e não há processo justo sem proteção à segurança jurídica e à confiança legítima no processo. 0 núcleo duro do direito à segurança jurídica e à confiança legítima no processo civil está encarnado principalmente na necessidade de proteção à coisa julgada. ${ }^{20}$

Moacyr Amaral Santos, citado por José Augusto Delgado, explica que "a procura da justiça não pode ser indefinida, mas deve ter um limite, por exigência de ordem pública, qual seja: a estabilidade dos direitos, que inexistiria se não houvesse um termo além do qual a sentença se tornou imutável". ${ }^{21}$

Dessa forma, e em consonância com o que foi explanado, o objetivo precípuo da coisa julgada material é a proteção daqueles que, após postularem a intervenção do Poder Judiciário para resolução dos seus conflitos e advindo deste órgão decisão final, pressupõem ter dado fim às controvérsias anteriormente estabelecidas, proporcionando segurança jurídica aos litigantes, de modo a tornar as relações estáveis.

\section{OS INSTRUMENTOS UTILIZADOS PARA DESCONSTITUIÇÃO DA COISA JULGADA NO PROCESSO CIVIL BRASILEIRO}

Não obstante a necessidade de um ordenamento jurídico garantir aos seus jurisdicionados segurança e estabilidade nas relações submetidas à apreciação judicial, existem hipóteses que mitigam a austeridade da coisa julgada, permitindo-se rever decisões consideradas imutáveis.

Exemplo disso são os feitos que versam acerca de relações continuativas, ${ }^{22}$ em que adveio modificação determinante no estado de fato ou de direito das partes envolvidas, seja para a procedência ou improcedência do pedido, acontecimento que torna legalmente possível a revisão da sentença já acobertada pelo manto da coisa julgada material, proferindo o

\footnotetext{
${ }^{20}$ MARINONI, Luiz Guilherme; MITIDIERO, Daniel. O projeto do CPC: crítica e propostas. São Paulo: Revista dos Tribunais, 2010, p. 44.

21 DELGADO, José Augusto. Efeitos da coisa julgada e os princípios constitucionais. São Paulo: II Seminário de Direito Ambiental Imobiliário, 1999. Disponível em: <http://www.pge.sp.gov.br/centrodeestudos/bibliotecavirtual/ambiental3/painel4.htm>. Acesso em: 20 dez. 2012.

${ }^{22}$ Hipótese amplamente difundida de relações continuativas é a da ação de alimentos, regida pela Lei $\mathrm{n}^{\circ}$ 5.478/1968, em que, havendo mudança da situação fática, ou seja, da necessidade do alimentado, ou da possibilidade do alimentante, é possível a alteração da sentença já acobertada pela coisa julgada material.
} 
magistrado outra decisão em conformidade com a realidade demonstrada na nova ação intentada.

Além dessa possibilidade, são previstas legal e doutrinariamente a ação rescisória, a ação declaratória de nulidade ou querela nullitatis, bem como a denúncia por violação à Convenção Americana de Direitos Humanos, que a seguir serão analisadas.

\subsection{Ação rescisória}

A sentença de mérito transitada em julgado poderá ser rescindida, segundo a previsão constante do artigo 485 do Código de Processo Civil, ${ }^{23}$ com o manejo de ação rescisória.

Essa ação tem cabimento somente em situações extraordinárias, sendo que as hipóteses para a sua propositura são arroladas em numerus clausus, ocorrendo quando: verificar-se que a sentença foi proferida por prevaricação, concussão ou corrupção do juiz; proferida por juiz impedido ou absolutamente incompetente; resultar de dolo da parte vencedora em detrimento da parte vencida, ou de colusão entre as partes, a fim de fraudar a lei; ofender a coisa julgada; violar literal disposição de lei; se fundar em prova, cuja falsidade tenha sido apurada em processo criminal, ou seja provada na própria ação rescisória; após a prolação da sentença, o autor obtiver documento novo, cuja existência ignorava, ou de que não pode fazer uso, capaz, por si só, de lhe assegurar pronunciamento favorável; houver fundamento para invalidar confissão, desistência ou transação, em que se baseou a sentença; ou, por fim, fundada em erro de fato, resultante de atos ou de documentos da causa.

Doutrinariamente se entende que é possivel a utilização da ação rescisória, ainda, para desconstituir a intangibilidade da sentença que violar a Constituição da República, com fulcro no artigo 485, V, do Código de Processo Civil, ${ }^{24}$ isso porque o termo "lei" deve ser interpretado em sentido amplo. ${ }^{25}$

A ação rescisória deverá ser proposta no prazo de dois anos, contados do trânsito em julgado da decisão, podendo ser ajuizada por quem foi parte no processo, ou o seu sucessor a título universal ou singular; pelo terceiro juridicamente interessado e pelo Ministério Público,

${ }^{23}$ CPC - Art. 485. A sentença de mérito, transitada em julgado, pode ser rescindida [...]. (BRASIL, op. cit., Código de Processo Civil).

${ }^{24}$ CPC - Art. 485. A sentença de mérito, transitada em julgado, pode ser rescindida quando: [...] V - violar literal disposição de lei. (Ibidem).

${ }^{25}$ MIRANDA, Francisco Cavalcanti Pontes de. Comentários ao Código de Processo Civil. vol. VI., 1. ed. São Paulo: Forense, 1975, p. 287. 
sendo este somente nas hipóteses de não ter sido parte integrante da relação processual em que era obrigatória sua intervenção, ou nos casos em que a sentença proferida é efeito de conluio entre as partes, com o objetivo de fraudar a lei.

0 pedido da ação rescisória poderá ser cumulativo, a teor do disposto no artigo 292 do Código de Processo Civil, ${ }^{26}$ pois, quando for o caso, deverá ser postulado, além da rescisão da sentença, o novo julgamento da causa.

Acerca do possível debate de aparente afronta à Constituição da República, tendo em vista que a ação rescisória visa rescindir a coisa julgada já operada, Celso Ribeiro Bastos e Ives Gandra Martins evidenciam que se a própria Constituição prevê a competência para o julgamento deste tipo de ação, é porque ela não a considera ofensiva da coisa julgada, ${ }^{27}$ não havendo falar, portanto, em inconstitucionalidade.

A ação rescisória é necessária para possibilitar o reexame de situações em que a imutabilidade da coisa julgada material acarretaria verdadeira afronta a princípios constitucionais e processuais, bem como ao próprio Estado Democrático de Direito.

Destarte, vê-se que sua utilização é necessária para garantir um sistema jurídico seguro, não configurando as decisões proferidas pelo Poder Judiciário motivo de descrença da sociedade.

\subsection{Ação declaratória de nulidade ou querela nullitatis}

Analisadas as hipóteses taxativas previstas no rol que permite a desconstituição da coisa julgada por meio da ação rescisória, verifica-se que a legislação infraconstitucional não contemplou determinadas circunstâncias, como é o caso das ações que tramitaram sem a observância dos pressupostos processuais de existência (petição inicial, jurisdição e citação), ou de alguma das condições da ação (possibilidade jurídica do pedido, legitimidade de parte e interesse de agir).

Nesses casos, Marinoni e Arenhart sustentam que, por não existir um processo, já que ausentes os pressupostos necessários para tanto, não há sentença a ser considerada, não comportando, por conseguinte, a imutabilidade proveniente da coisa julgada, concluindo que, "se não existe, aí, coisa julgada, inexiste espaço para o cabimento de ação rescisória contra tais

${ }^{26}$ CPC - Art. 292. É permitida a cumulação, num único processo, contra o mesmo réu, de vários pedidos, ainda que entre eles não haja conexão. (BRASIL, op. cit., Código de Processo Civil).

27 BASTOS, Celso Ribeiro; MARTINS, Ives Gandra. Comentários à Constituição do Brasil: promulgada em 5 de outubro de 1988. vol. 2. São Paulo: Saraiva, 1989, p. 201. 
atos", ${ }^{28}$ devendo o legitimado, para ver reconhecida a inexistência do ato judicial, valer-se da ação declaratória de nulidade, comumente denominada querela nullitatis, que não possui previsão legal, sendo construção doutrinária.

Didier Junior, Braga e Oliveira acrescentam que "a querela nullitatis é meio de impugnação de decisão maculada por vícios transrescisórios". ${ }^{29}$ Assim, é utilizada em hipóteses excepcionais de nulidades absolutas, com o escopo de desconstituir a sentença proferida, diferenciando-se da ação rescisória por não se submeter a prazo decadencial.

\subsection{Denúncia por violação à convenção americana de direitos humanos}

Após a Segunda Guerra Mundial, houve um intenso processo de internacionalização dos direitos humanos, visando à proteção do indivíduo como sujeito de direitos na esfera internacional.

Criou-se, a partir de então, um Sistema Normativo Internacional de proteção aos direitos humanos, sendo este dividido em: (a) Sistema Global, que possui como principal documento a Declaração Universal de Direitos Humanos e um (b) Sistema Regional, que é subdividido em: b.1) Sistema Interamericano; b.2) Sistema Africano e b.3) Sistema Europeu. Tanto o Sistema Global quanto o Sistema Regional não se excluem, sendo um complementado pelo outro.

No Brasil, além do Sistema Global, vige também o Sistema Regional Interamericano, cujo principal documento é a Convenção Americana de Direitos Humanos, também denominado de Pacto de San José da Costa Rica, promulgado pelo Brasil em 06 de novembro de 1992.

Essa Convenção criou a Corte e a Comissão Interamericana de Direitos Humanos, que possuem como função o conhecimento de assuntos relacionados ao cumprimento dos compromissos assumidos pelos países que integram a Organização dos Estados Americanos (OEA) e que reconheçam a sua jurisdição.

Em que pese a promulgação e a determinação, por meio do decreto presidencial, de que a Convenção fosse inteiramente cumprida, a jurisdição da Corte Interamericana no Brasil

${ }^{28}$ MARINONI, Luiz Guilherme; ARENHART, Sérgio Cruz, op. cit., p. 671.
${ }^{29}$ DIDIER JUNIOR, Fredie; BRAGA, Paula Sarno; OLIVEIRA, Rafael, op. cit., p. 553. 
ocorreu somente em 03 de dezembro de 1998, quando, por meio do Decreto Legislativo $\mathrm{n}^{\circ} 89,{ }^{30}$ o Congresso Nacional aprovou o reconhecimento da sua competência.

Portanto, desde 1998, é possível que qualquer pessoa, grupo de pessoas, ou entidade não-governamental, encaminhe petição à Comissão Interamericana, relatando "ato ou omissão estatal brasileiro (executivo, legislativo ou jurisdicional), inclusive decisões judiciais já acobertadas pela coisa julgada material que violem garantias fundamentais". ${ }^{31}$

Sobre o tema, Eduardo Talamini refere que “ao lado dos remédios 'internos' de revisão da coisa julgada acima citados, cuja apreciação cabe aos órgãos jurisdicionais nacionais, subsiste um remédio 'externo', cujo exame compete a tribunal internacional”. ${ }^{32}$

A desconstituição da coisa julgada, utilizando-se do instituto ora analisado, é comumente visualizada no âmbito processual penal, por violação à ampla defesa e ao contraditório. A rescisão da coisa julgada, contudo, é possível também na esfera civil, quando, por exemplo, "a Corte Interamericana viesse a revisar uma desapropriação feita em violação aos direitos fundamentais". ${ }^{33}$

Didier Junior relata, ainda, que "um processo internacional, instaurado perante este tribunal, pode ter por objeto mediato ou imediato o rejulgamento (em termos incompatíveis com o julgamento interno) ou a invalidação de sentença brasileira transitada em julgado", ${ }^{34}$ o que revela mais um meio previsto no ordenamento jurídico capaz de relativizar a coisa julgada.

\section{OS CONTROLES JURISDICIONAIS DE CONSTITUCIONALIDADE NO ORDENAMENTO JURÍDICO BRASILEIRO E SEUS EFEITOS}

A austeridade e supremacia constitucionais determinam que todas as demais normas infraconstitucionais observem os seus preceitos formais e materiais, que dizem respeito, respectivamente, ao procedimento de elaboração legislativa e à adequação do conteúdo da lei com o que dispõe a Constituição da República.

30 BRASIL. Decreto legislativo $\mathrm{n}^{\circ}$ 89. Brasília: Congresso Nacional, 1998. Disponível em: <http://www6.senado.gov.br/legislacao/ListaPublicacoes.action?id=150844>. Acesso em: 20 dez. 2012.

${ }^{31}$ DIDIER JUNIOR, Fredie; BRAGA, Paula Sarno; OLIVEIRA, Rafael, op. cit, p. 581.

32 TALAMINI, Eduardo. Meios de impugnação ao julgado civil. Rio de Janeiro: Forense, 2007, p. 157. Apud: Ibidem, p. 579.

${ }^{33}$ Ibidem, p 157. Apud: Ibidem, p. 579.

${ }^{34}$ Ibidem, p. 581. 
0 controle de constitucionalidade será preventivo, quando realizado no momento do projeto de lei ou ato normativo, ${ }^{35}$ ou repressivo, exercido após a promulgação da lei.

No Brasil, o controle repressivo é híbrido, podendo ser exercido em sua forma difusa ou concentrada.

\subsection{Controle Difuso}

O controle difuso, previsto no artigo 102, III, da Constituição da República, ${ }^{36}$ é exercido de forma incidental no processo já em curso, onde as próprias partes, o terceiro interveniente e - Ministério Público poderão suscitar, bem como o julgador declarar, ex officio, a inconstitucionalidade de determinada lei que embasa a pretensão de alguma das partes, sendo resolvida nos mesmos autos da questão principal e anteriormente a esta.

0 juiz singular e os tribunais poderão declarar a lei inconstitucional e afastar a sua aplicação, sendo que a declaração deverá ocorrer com votos da maioria absoluta dos julgadores, quando o julgamento for proveniente dos tribunais. ${ }^{37}$

Quanto aos seus efeitos, estes são retroativos, “isto é, opera retroativamente em relação ao caso que deu motivo à decisão (e, repita-se, só em relação a este), fulminando, desde o seu nascimento, a relação jurídica fundada na lei inconstitucional". ${ }^{38-39}$

A eficácia da decisão proferida é, regra geral, inter partes, porquanto a inconstitucionalidade da lei é controvertida entre as partes litigantes e o julgador apreciará este tema como questão prejudicial para resolução do caso concreto sub judice, ainda que existam outros casos análogos.

\footnotetext{
${ }^{35}$ É o controle político, exercido pelos poderes legislativo e executivo.

${ }^{36}$ CR - Art. 102. Compete ao Supremo Tribunal Federal, precipuamente, a guarda da Constituição, cabendo-lhe: [...] III - julgar, mediante recurso extraordinário, as causas decididas em única ou última instância, quando a decisão recorrida: a) contrariar dispositivo desta Constituição; b) declarar a inconstitucionalidade de tratado ou lei federal; c) julgar válida lei ou ato de governo local contestado em face desta Constituição. (BRASIL, op. cit., Constituição da República Federativa do Brasil).

${ }^{37}$ CR - Art. 97. Somente pelo voto da maioria dos seus membros ou dos membros do respectivo órgão especial poderão os Tribunais declarar a inconstitucionalidade de lei ou ato normativo do Poder Público. (Ibidem).

${ }^{38}$ PAULO, Vicente; ALEXANDRINO, Marcelo. Controle de constitucionalidade. 8. ed. São Paulo: Método, 2009, p. 50.

39 Pedro Lenza, embasado em entendimento do Supremo Tribunal Federal, entende ser possível a atenuação do princípio da nulidade no controle difuso, oportunidade em que a decisão terá efeitos ex nunc. (LENZA, Pedro. Direito constitucional esquematizado. 13. ed. rev., atual. e amp. São Paulo: Saraiva, 2009, p. 155).
} 
Todavia, é possível que a decisão seja oponível erga omnes, o que ocorreria nas hipóteses em que o Supremo Tribunal Federal, por meio de Recurso Extraordinário, declara a inconstitucionalidade de lei pela via difusa, e o Senado Federal, em cumprimento ao que dispõe o artigo 52, X, da Constituição da República, ${ }^{40}$ discricionariamente, suspende, por meio de resolução, a execução da lei.

Quanto aos efeitos produzidos pela resolução, verifica-se grande dissenso doutrinário. Majoritariamente, segue-se o entendimento de que possui efeitos ex nunc ou prospectivos, ao argumento de que a palavra "suspensão", inserida no texto legal, colige à ideia de que a lei estava produzindo seus efeitos e, devido à resolução, estes foram suspensos. ${ }^{41}$

Contudo, parcela significativa da doutrina ${ }^{42}$ ensina que a resolução do Senado Federal teria eficácia ex tunc, retroagindo ao nascimento do texto legal, fazendo com que todas as relações estabelecidas sob a égide da lei inconstitucional sejam desconstituídas.

Essa doutrina parece a mais adequada, tendo-se em vista a desnecessidade de ingresso no Poder Judiciário com inúmeras novas ações judiciais, objetivando, analogamente, desconstituir, pela via incidental, as relações jurídicas de direito material sustentadas pela lei inconstitucional, assim já declarada pelo Supremo Tribunal Federal no julgamento de determinado caso concreto.

Acerca desse instrumento de controle de constitucionalidade, bem como da sua importância no ordenamento jurídico, Marcelo Figueiredo enfatiza que

\begin{abstract}
a grande virtude do controle difuso de constitucionalidade está exatamente na sua coerência e simplicidade. A possibilidade de qualquer juiz negar aplicação à lei ordinária que confronte a constituição é admirável. Possibilita que todo o Judiciário analise e confronte a constitucionalidade da lei e dos demais atos normativos. ${ }^{43}$
\end{abstract}

\footnotetext{
${ }^{40} \mathrm{CR}$ - Art. 52. Compete privativamente ao Senado Federal: [...] X - suspender a execução, no todo ou em parte, de lei declarada inconstitucional por decisão definitiva do Supremo Tribunal Federal. (BRASIL, op. cit., Constituição da República Federativa do Brasil).

${ }^{41}$ Nesse sentido: LENZA, Pedro, op. cit., p. 184, que embasa seu posicionamento nos doutrinadores Themístocles Cavalccanti, Oswaldo Aranha Bandeira de Mello, José Afonso da Silva, Regina Nery Ferrari, entre outros. Segue o mesmo posicionamento: FERREIRA, Olavo A. V. Alves. Controle de Constitucionalidade e seus efeitos. São Paulo: Método, 2005, p. 65-66.

${ }^{42}$ Nesse sentido: Clemerson Merlim Clève, Gilmar Ferreira Mendes, Marcello Caetano, citados por Olavo A. V. Alves Ferreira (FERREIRA, Olavo A. V. Alves, op. cit., p. 66) e Uadi Lammêgo Bulos (BULOS, Uadi Lammêgo, op. cit, p. 148).

${ }^{43}$ FIGUEIREDO, Marcelo. O controle de constitucionalidade - algumas notas e preocupações, p. 10. Apud: FERREIRA, Olavo A. V. Alves, op. cit., p. 40.
} 
Assim, é dever dos magistrados realizar o controle de constitucionalidade das leis que irão aplicar em todos os casos concretos analisados, ainda que não haja arguição pelas partes de eventual inconstitucionalidade, com o que se terá um sistema jurídico uniforme, garantindo aos jurisdicionados uma decisão de acordo com as normas e princípios constitucionais.

\subsection{Controle Concentrado}

O controle concentrado de constitucionalidade, por sua vez, opera-se in abstracto, pois o seu objetivo principal é analisar a (in) constitucionalidade da lei em tese, sem aplicá-la a nenhum caso específico. São institutos desse controle as ações: direta de inconstitucionalidade, que se subdivide em genérica, interventiva e por omissão; declaratória de constitucionalidade, e, por fim, a arguição de descumprimento de preceito fundamental.

Para o desenvolvimento desse estudo se revela fundamental a análise mais aprofundada somente da ação direta de inconstitucionalidade genérica, pois este mecanismo permite a apreciação da inconstitucionalidade da lei ou ato normativo que, em tese, afronta as regras e princípios constantes na Constituição da República, visando o consenso das normas jurídicas.

Essa ação é prevista constitucionalmente no artigo 102, I, a, da Constituição da República $^{44}$ e regulamentada pela Lei $n^{\circ}$ 9.868/1999. Seu julgamento será realizado, originariamente, pelo Supremo Tribunal Federal.

Podem ser objeto de ação direta de inconstitucionalidade leis ou atos normativos federais ou estaduais ${ }^{45}$ em virtude da Constituição da República.

Considerando que, ao julgar inconstitucional uma lei ou ato normativo, o Supremo Tribunal Federal não cria nova lei, apenas retira do ordenamento jurídico a lei considerada inconstitucional, o estudo dos efeitos desta decisão é de suma importância. Sobre o tema, Paulo Vicente e Marcelo Alexandrino sintetizam que a decisão, em regra, é dotada de "eficácia contra

\footnotetext{
${ }^{44}$ CR - Art. 102. Compete ao Supremo Tribunal Federal, precipuamente, a guarda da Constituição, cabendo-lhe: I - processar e julgar, originariamente: a) a ação direta de inconstitucionalidade de lei ou ato normativo federal ou estadual [...].(BRASIL, op. cit., Constituição da República Federativa do Brasil).

${ }_{45}$ As leis e atos normativos distritais, conforme uníssono entendimento doutrinário, somente poderão ser impugnados por meio de Ação Direta de Inconstitucionalidade se editados no exercício da competência estadual do Distrito Federal, visto que leis e atos normativos municipais não poderão ser objetos desta ação.
} 
todos (erga omnes); efeitos retroativos (ex tunc); efeito vinculante; efeito repristinatório em relação à legislação anterior". ${ }^{46}$

Serão erga omnes, pois a declaração é oponível contra todos e vinculantes, em razão de vincular os poderes Executivo e Judiciário. Quanto aos efeitos repristinatórios, se a declaração de inconstitucionalidade tiver efeitos ex tunc, ${ }^{47}$ a revogação que a lei inconstitucional havia realizado se torna sem efeito, fazendo com que volte a ser aplicada a norma anterior. ${ }^{48}$

Por fim, possui efeitos retroativos, visto que a declaração de inconstitucionalidade proferida pelo Supremo Tribunal Federal "retira a lei do ordenamento jurídico desde a sua origem, atinge os atos com base nela praticados e desautoriza a invocação de qualquer direito com fundamento no diploma legal". ${ }^{49}$

Assim, fala-se em sanção de nulidade ou anulabilidade da lei ou ato normativo que contenha o vício da inconstitucionalidade.

Segundo Uadi Lammêgo Bulos, "no regime da sanção de nulidade a sentença de inconstitucionalidade é declaratória e o ato inconstitucional é nulo desde a origem, retroagindo ao momento do seu ingresso na ordem jurídica", afirmando ser este o regime adotado no ordenamento brasileiro. ${ }^{50}$ Nessa mesma direção, Bastos, citado por Ferreira, ensina que "toda norma infringente da Constituição é nula". ${ }^{51}$

Além disso, Marinoni afirma que a decisão da ação direta "não possui caráter desconstitutivo, e por isso não apenas revoga a lei. A sua natureza é declaratória, pois reconhece a nulidade da lei, vale dizer, um estado já existente". ${ }^{52}$

0 artigo 27 da lei $n^{\circ} 9868 / 1999,{ }^{53}$ entretanto, trouxe um limite ao efeito ex tunc, influindo no conceito de nulidade da lei inconstitucional, ao qual Pedro Lenza denomina “declaração de inconstitucionalidade sem a pronúncia de nulidade". ${ }^{54}$

\footnotetext{
${ }^{46}$ PAULO, Vicente; ALEXANDRINO, Marcelo, op. cit., p. 99.

${ }^{47}$ Fala-se na possibilidade da decisão possuir efeitos ex tunc tendo em vista que, como a seguir será abordado, existe também a possibilidade de modulação desses efeitos pelo Supremo Tribunal Federal, hipótese em que terá efeitos ex nunc.

${ }^{48}$ PAULO, Vicente; ALEXANDRINO, Marcelo, op. cit., p. 102.

${ }^{49}$ Ibidem, p. 100.

${ }_{51}^{50}$ BULOS, Uadi Lammêgo, op. cit, p. 89.

${ }^{51}$ FERREIRA, Olavo A. V. Alves, op. cit., p. 29.

${ }^{52}$ MARINONI, Luiz Guilherme. Sobre a chamada "relativização“ da coisa julgada material. Disponível em: <http://www.abdpc.org.br/abdpc/artigos/Luiz\%20G\%20Marinoni\%2814\%29\%20-formatado.pdf>. Acesso em: 20 dez. 2012.

${ }^{53}$ Lei n ${ }^{\circ}$ 9868/1999 - Art. 27. Ao declarar a inconstitucionalidade de lei ou ato normativo, e tendo em vista razões de segurança jurídica ou de excepcional interesse social, poderá o Supremo Tribunal Federal, por maioria de dois terços de seus membros, restringir os efeitos daquela declaração ou decidir que ela só
} 
Assim procedendo, o Supremo Tribunal Federal estará conferindo à decisão declaratória de inconstitucionalidade efeitos ex nunc.

Embora renomada doutrina ${ }^{55}$ entenda pela inconstitucionalidade do dispositivo supracitado, sobretudo com fundamento no princípio da supremacia constitucional e em razão da sentença que decreta a inconstitucionalidade ser declaratória, o que acarreta a nulidade da lei desde o seu nascimento, calha transcrever o entendimento divergente de Bulos, lecionando que "a regra do regime da sanção de nulidade não é um dogma imutável e absoluto, insuscetível de flexibilizações e abrandamentos". ${ }^{56}$

O mesmo doutrinador conclui:

Isso não significa, de modo algum, o abandono da regra que homenageia os efeitos gerais ou erga omnes no controle concentrado. Trata-se, apenas, da consagração do princípio que permite ao órgão de cúpula do Poder Judiciário - a exemplo do nosso Supremo Tribunal Federal - manipular os efeitos da declaração abstrata de inconstitucionalidade, com larga dose de discricionariedade e razoabilidade, ponderando interesses em disputa. ${ }^{57}$

Ademais, Miranda, com maestria, acerca da inexistência de decisões puras, ensina que "as classes dessas decisões ${ }^{58}$ são determinadas por preponderância de eficácia das decisões", ${ }^{59}$ ao que se dá o nome de força da sentença. Assim, "qualquer decisão favorável sobre questão de inconstitucionalidade é constitutiva negativa: qualquer decisão desfavorável, declarativa". ${ }^{60}$ Logo, em razão da força constitutiva, ${ }^{61}$ anula-se a lei ou ato normativo a partir da publicação da decisão de inconstitucionalidade.

tenha eficácia a partir de seu trânsito em julgado ou de outro momento que venha a ser fixado. (BRASIL. Lei $\mathrm{n}^{\circ}$ 9868/1999. Brasília: Congresso Nacional, 1999. Disponível em: <http://www.planalto.gov.br/ccivil_03/leis/L9868.htm>. Acesso em: 20 dez. 2012).

${ }^{54}$ LENZA, Pedro, op. cit., p. 235.

${ }^{55}$ Nesse sentido Ferreira, que cita, entre outros, os doutrinadores Ingo Wolfgang Sarlet, Silvio Nazareno Costa, Ives Gandra da Silva Martins e Elival da Silva Ramos. (FERREIRA, Olavo A. V. Alves, op. cit., p. 935).

${ }^{56}$ BULOS, Uadi Lammêgo, op. cit., p. 257.

${ }^{57}$ Ibidem, p. 260.

58 Pontes de Miranda se refere à distribuição das decisões jurídicas em declaratórias, constitutivas, condenatórias, mandamentais e executivas.

${ }_{59}$ MIRANDA, Francisco Cavalcanti Pontes de. Comentários à constituição de 1967. Tomo III. São Paulo: Revista dos Tribunais, 1967, p. 590.

${ }^{60}$ Ibidem, p. 597.

${ }^{61}$ Pelo processo constitutivo chega-se à declaração peculiar a todas as sentenças de mérito (provimentos jurisdicionais de conhecimento); com o acréscimo da modificação de uma situação jurídica anterior, criando-se uma nova. (CINTRA, Antonio Carlos de Araújo; DINAMARCO, Cândido Rangel; GRINOVER, Ada Pellegrini, op.cit., p. 327). 
Acerca do tema, José Joaquim Gomes Canotilho, citado por Olavo A. V. Alves Ferreira, doutrina que

nos sistemas de controlo concentrado a regra geral consiste em atribuir à decisão de inconstitucionalidade um efeito constitutivo. 0 órgão que decide sobre a inconstitucionalidade anula um acto normativo que até ao momento da decisão é considerado válido e eficaz. É o regime geral do controlo concentrado. Como se acaba de explicar, o controlo concentrado, de acordo com as premissas teorético-jurídicas de Kelsen e de Merkl, parte da ideia de as 'leis inconstitucionais' deverem ser consideradas como 'leis constitucionais' até serem eliminadas do ordenamento jurídico [...]. ${ }^{62}$

Admitindo-se os efeitos ex tunc da decisão na ação direta de inconstitucionalidade, é necessária a análise acerca da influência deste julgamento na coisa julgada material, verificando-se se a sentença lastreada em aplicação de lei ou ato normativo, posteriormente considerado inconstitucional pelo Supremo Tribunal Federal, deve subsistir, ou deverá prevalecer a teoria da relativização.

\section{A TEORIA DA RELATIVIZAÇÃO DA COISA JULGADA INCONSTITUCIONAL}

A teoria da relativização da coisa julgada inconstitucional ${ }^{63}$ defende que, quando declarada inconstitucional pelo Supremo Tribunal Federal uma determinada lei, as sentenças já acobertadas pela coisa julgada, que tiveram como fundamento a norma inconstitucional, poderão ser novamente analisadas pelo Poder judiciário, já que, em razão da contrariedade às disposições constitucionais, não poderão subsistir.

Consigne-se que o estudo da relativização da coisa julgada inconstitucional pressupõe a existência de decisão do Supremo Tribunal Federal, em ação direta de inconstitucionalidade ou em controle difuso, quando, nesta hipótese, houver a suspensão da execução da norma pelo Senado Federal, e, em ambos os casos, as decisões possuam efeitos ex tunc.

Acerca do tema, importante referir que parte da doutrina ${ }^{64}$ argui que as disposições dos artigos 475-L, $\S 1^{\circ},{ }^{65}$ e 741, parágrafo único, ${ }^{66}$ do Código de Processo Civil, são previsões legais

\footnotetext{
${ }^{62}$ FERREIRA, Olavo A. V. Alves, op. cit., p. 80.

${ }^{63}$ A terminologia empregada é amplamente difundida na doutrina, contudo, faz-se necessário registrar que "mais bem se chamaria sentença inconstitucional transitada em julgado. A rigor, o que contraria a Constituição não é a coisa julgada, mas o conteúdo da sentença." (CÂMARA, Alexandre de Freitas, op. cit., p. 499).

${ }^{64}$ Nesse sentido: DIDIER JUNIOR, Fredie; BRAGA, Paula Sarno; OLIVEIRA, Rafael, op. cit., p. 531.
} 
dessa teoria, em que a impugnação, em sede de execução ao cumprimento da sentença, é verdadeiro óbice à execução do título judicial fundado em aplicação de lei tida pelo Supremo Tribunal Federal como incompatível com a Constituição da República, o que, em tese, acarretaria na relativização da coisa julgada inconstitucional.

Entretanto, nessas hipóteses legais, afigura-se que não há falar em relativização da coisa julgada material, já que essas regras se constituem apenas em óbices à exigibilidade do título. Nesse sentido, Beclaute Oliveira Silva constata que "a lei reputa o título executivo judicial existente juridicamente. Além disso, não questiona a coisa julgada. Esse dispositivo não está rescindindo a sentença ou decretando a sua invalidade. Pelo contrário a sentença permanece incólume". ${ }^{67}$

Dessa forma, em que pese ter havido um avanço acerca da temática, depreende-se que não houve solução para o problema em questão, pois, mesmo que aplicados os dispositivos em comento, a situação ainda exigiria a relativização da coisa julgada inconstitucional para possibilitar um novo julgamento, embora o título executivo seja inexigível.

No Brasil, a teoria da relativização da coisa julgada foi abordada, inicialmente, pelo exministro do Superior Tribunal de Justiça, Delgado, para quem a

sentença transitada em julgado pode ser revista, além do prazo para rescisória, quando a injustiça nela contida for de alcance que afronte a estrutura do regime democrático por conter apologia da quebra da moralidade, da legalidade, do respeito à Constituição Federal e às regras da natureza. ${ }^{68}$

Afirma o jurista, ainda, que não se poderia aceitar,

\footnotetext{
${ }^{65}$ CPC - Art. 475-L. A impugnação somente poderá versar sobre: [...] $\S 1^{0}$ Para efeito do disposto no inciso II do caput deste artigo, considera-se também inexigível o título judicial fundado em lei ou ato normativo declarados inconstitucionais pelo Supremo Tribunal Federal, ou fundado em aplicação ou interpretação da lei ou ato normativo tidas pelo Supremo Tribunal Federal como incompatíveis com a Constituição Federal. (BRASIL, op. cit., Código de Processo Civil).

${ }^{66}$ CPC - Art. 741, parágrafo único. Para efeito do disposto no inciso II do caput deste artigo, considera-se também inexigível o título judicial fundado em lei ou ato normativo declarados inconstitucionais pelo Supremo Tribunal Federal, ou fundado em aplicação ou interpretação da lei ou ato normativo tidas pelo Supremo Tribunal Federal como incompatíveis com a Constituição Federal. (Ibidem).

${ }^{67}$ SILVA, Beclaute Oliveira. Coisa julgada baseada em lei inconstitucional (?): Considerações acerca da teoria Pontiana. Disponível em: <http://www.procuradoria.al.gov.br/centro-deestudos/artigos/COISA\%20JULGADA\%2OINCONSTITUCIONAL.pdf>. Acesso em: 20 dez. 2012.

68 DELGADO, José Augusto, op. cit. Disponível em: <http://www.pge.sp.gov.br/centrodeestudos/bibliotecavirtual/ambiental3/painel4.htm>. Acesso em: 20 dez. 2012.
} 
em sã consciência, que, em nome da segurança jurídica, a sentença viole a Constituição Federal, seja veículo de injustiça, desmorone ilegalmente patrimônios, obrigue o Estado a pagar indenizações indevidas, finalmente, que desconheça que o branco é branco e que a vida não pode ser considerada morte, nem vice-versa. ${ }^{69}$

A partir dessa abordagem, outros doutrinadores passaram a manifestar seus entendimentos acerca do tema.

Câmara adverte que, "não obstante ser a coisa julgada material a imutabilidade e indiscutibilidade do conteúdo da sentença de mérito, casos há em que é preciso desconsiderála", ${ }^{70}$ como na hipótese de inconstitucionalidade da decisão, que configura um vício insanável.

José Afonso da Silva destaca que a coisa julgada inconstitucional, além de vício insanável, é considerada "ato inexistente, segundo opinião daqueles que entendem que o ato inconstitucional é nulo, sem efeito, portanto pode ser desconstituído a qualquer tempo". ${ }^{71}$

Nesse mesmo sentido Teresa Arruda Alvim Wambier e José Miguel Garcia Medina lecionam que "a decisão que seria alvo de impugnação seria juridicamente inexistente, pois que baseada em 'lei' que não é lei ('lei inexistente')". ${ }^{72}$

Assim, não haveria alternativa, senão relativizar a coisa julgada já operada, para que a decisão esteja em consonância com as disposições da Constituição da República.

Para Francisco Barros Dias a coisa julgada está alicerçada

na segurança, estabilidade e certeza jurídicas, quando há apenas violação de norma infraconstitucional, o que não se pode dizer, igualmente, com relação a uma norma constitucional violada. Aí, esses princípios que fundamentam a coisa julgada não são suficientes para mantê-la de forma definitiva, porque a lei maior é que restou violada, comprometendo assim o berço de todo o sistema. ${ }^{73}$

Afonso da Silva, no que concerne à proteção da coisa julgada, em que é preceituado que a lei não a prejudicará, ainda esclarece que "quer-se tutelar esta contra a atuação direta do

\footnotetext{
69 Ibidem.

${ }^{70}$ CÂMARA, Alexandre de Freitas, op. cit., p. 497.

71 SILVA, José Afonso da. Comentário contextual à Constituição. 2. ed. São Paulo: Malheiros, 2006, p. 135.

72 WAMBIER, Teresa Arruda Alvim, MEDINA, José Miguel Garcia. O dogma da coisa julgada. São Paulo: RT, 2003, p. 43.

73 DIAS, Francisco Barros. Breve análise sobre a coisa julgada inconstitucional. Disponível em: <http://www.jfrn.jus.br/institucional/biblioteca/doutrina/doutrina129.doc>. Acesso em: 20 dez. 2012.
} 
legislador", ${ }^{74}$ afirmando Dias que "quer isso dizer que o legislador, ao criar uma lei, não pode ofender o caso julgado, como garantia de que o Judiciário ao decidir, deve ter sua decisão respeitada, de modo a se traduzir a independência dos Poderes". ${ }^{75}$ Portanto, seguindo este entendimento, a disposição do artigo $5^{\circ}$, XXXVI, da Constituição da República não é óbice à relativização da coisa julgada, devido à inconstitucionalidade constatada na sentença.

Theodoro Júnior e Juliana Cordeiro de Faria, referente à necessidade de relativizar a coisa julgada inconstitucional, explicitam que "a coisa julgada não pode suplantar a lei, em tema de inconstitucionalidade, sob pena de transformá-la em um instituto mais elevado e importante que a lei e a própria Constituição."76

Para evitar distorções sobre a teoria, tornando-a corriqueira, Theotonio Negrão e José Roberto Ferreira Gouvêa, registram a excepcionalidade da medida, pois “a ideia de relativização da coisa julgada material consiste no excepcional afastamento de sua eficácia, a fim de que um outro valor igualmente caro ao ordenamento jurídico sobre ela prevaleça, por falar mais alto do que a imutabilidade do julgado no específico caso concreto". ${ }^{77}$

Ainda que não versassem sobre o assunto ora abordado, os dizeres de Bastos e Martins se coadunam aos argumentos defensivos expostos:

Se é certo, portanto, que a coisa julgada é uma garantia importante a proteger as situações já consolidadas no passado, o certo é que ela tem de amoldar-se a imperativos outros, resultantes de circunstâncias em que há razões mais fortes a serem feitas valer do que a mera imutabilidade do já decidido. ${ }^{78}$

Assim, lembra Afonso da Silva que surge um conflito: de um lado a defesa da Constituição e de outro a segurança jurídica. ${ }^{79}$

Oportuno referir que parte da doutrina, com sustentações veementemente contrárias à corrente defensiva, embasa sua tese, principalmente, na necessidade de um ordenamento que

74 SILVA, José Afonso da. Curso de direito constitucional positivo. 22. ed., rev. e atual. São Paulo: Malheiros, 2003, p. 435.

75 DIAS, Francisco Barros, op. cit. Disponível em: <http://www.jfrn.jus.br/institucional/biblioteca/doutrina/doutrina129.doc>. Acesso em: 20 dez. 2012.

76 THEODORO JÚNIOR, Humberto; FARIA, Juliana Cordeiro de. A coisa julgada inconstitucional e os instrumentos processuais para o seu controle. São Paulo: Revista dos Tribunais, 2002, p. 133. Apud: ARAÚJO, Marcelo Cunha de. Coisa julgada inconstitucional: Hipóteses de flexibilização e procedimentos para impugnação. Rio de Janeiro: Lumen Juris, 2007, p. 23.

${ }_{77}$ NEGRÃO, Theotonio; GOUVÊA, José Roberto Ferreira. Código de Processo Civil e legislação processual em vigor. 40. ed. São Paulo: Saraiva, 2008, p. 574.

${ }^{78}$ BASTOS, Celso Ribeiro; MARTINS, Ives Gandra, op. cit., p. 201.

${ }^{79}$ SILVA, José Afonso da, op. cit., Comentário [...], p. 135. 
garanta segurança jurídica àqueles que tiveram suas controvérsias submetidas à decisão do Poder Judiciário, sendo essa segurança, indubitavelmente, garantida pela coisa julgada, que é “elemento estruturante do Estado Democrático de Direito". 80

Dentre os opositores da relativização da coisa julgada com base em inconstitucionalidade da lei que fundamentou a decisão, Didier Junior, Braga e Oliveira dispõem ser essa teoria "problemática, pois a qualquer momento que a lei em que se fundou a decisão fosse reputada inconstitucional a decisão poderia ser desconstituída. Com isso, malferir-se-ia frontalmente a garantia da segurança jurídica". ${ }^{81}$

Quanto ao particular, Leonardo Greco assevera ser a coisa julgada "uma importante garantia fundamental e, como tal, um verdadeiro direito fundamental, como instrumento indispensável à eficácia concreta do direito à segurança, inscrito como valor e como direito no preâmbulo e no caput do artigo $5^{\circ}$ da Constituição de 1988 ". ${ }^{82}$

Bulos aduz que, ao aplicar uma lei ao caso concreto, "há a presunção absoluta de que o direito foi aplicado corretamente ao caso sub judice", ${ }^{83}$ o que impossibilitaria a desconsideração da coisa julgada após o prazo para ação rescisória. Para o doutrinador, deve-se sempre garantir a coisa julgada, sem a qual "a instabilidade e o caos estariam implantados". ${ }^{84}$

Lenza, doutrinador também contrário à aplicação da teoria da relativização, fundamenta seu posicionamento nos ensinamentos do ministro do Supremo Tribunal Federal, Gilmar Ferreira Mendes, que dispõe se tratar de “proteção ao ato singular, em homenagem ao princípio da segurança jurídica, procedendo-se à diferenciação entre o efeito da decisão no plano normativo (Normebene) e no plano do ato singular (Einzelaktebene) mediante a utilização de fórmulas de preclusão". ${ }^{85}$

A utilização das fórmulas de preclusão, como explica o próprio ministro no seu voto no Agravo Regimental no Recurso Extraordinário n²17.141-5/SP, faz com que “os atos praticados

\footnotetext{
${ }^{80}$ MARINONI, Luiz Guilherme. Coisa julgada inconstitucional. 2. ed. rev. e atual. São Paulo: Revista dos Tribunais, 2010, p. 7.

${ }^{81}$ DIDIER JUNIOR, Fredie; BRAGA, Paula Sarno; OLIVEIRA, Rafael, op. cit., p. 584.

82 GRECO, Leonardo. Eficácia da declaração erga omnes de constitucionalidade ou inconstitucionalidade em relação à coisa julgada anterior. Disponível em: <http://www.mundojuridico.adv.br/cgi-bin/upload/texto167.rtf >. Acesso em: 20 dez. 2012.

${ }^{83}$ BULOS, Uadi Lammêgo, op. cit., p. 492.

84 Ibidem, p. 258.

${ }^{85}$ LENZA, Pedro, op. cit., p. 242.
} 
com base na lei inconstitucional que não mais se afigurem suscetíveis de revisão não são afetados pela declaração de inconstitucionalidade". ${ }^{86}$

Nery Junior explica:

À sentença transitada em julgado, que eventualmente padeça do vício da inconstitucionalidade, não pode ser dado o mesmo tratamento da lei ou ato normativo inconstitucional. Este último é norma geral, editado de forma objetiva e no interesse geral. A sentença é lei (norma de caráter privado), editada de forma subjetiva e no interesse particular. ${ }^{87}$

Refere a doutrina oposicionista, ainda, ser a relativização da coisa julgada inconstitucional contrária ao mecanismo de controle de constitucionalidade adotado pelo ordenamento jurídico pátrio, porque este sistema permite que o juiz de primeira instância, ou os magistrados que conheceram da causa por meio de recurso, verifique a constitucionalidade da lei a ser aplicada no caso concreto. A respeito, Marinoni leciona:

A decisão transitada em julgado, assim, não pode ser invalidada como se constituísse mera declaração ou aplicação da lei, mais tarde pronunciada inconstitucional. A decisão judicial é o resultado da interpretação de um juiz dotado do dever de controlar a constitucionalidade no caso concreto, e, portanto, não pode ser pensada como uma decisão que se limita a aplicar uma lei posteriormente declarada inconstitucional. ${ }^{88}$

Registre-se que Nery Junior rechaça até mesmo a aplicação excepcional da relativização da coisa julgada inconstitucional, porquanto, acaso permitida, "a cultura jurídica brasileira vai, seguramente, alargar os seus espectros [...], de sorte que amanhã poderemos ter como regra a não existência da coisa julgada e como exceção, para pobres e não poderosos, a intangibilidade da decisão". 89

Ademais, Marinoni e Mitidiero afirmam que não haverá Estado Constitucional, tampouco um processo justo, sem proteção à coisa julgada, repisando que "é inconstitucional qualquer tentativa de se instruir expediente no Código de Processo Civil que vise à desconsideração da

\footnotetext{
${ }^{86}$ BRASIL. Supremo Tribunal Federal. Agravo regimental no recurso extraordinário $n^{\circ}$ 217.141-5/SP. Neusa Gomes Delgado e Instituto de Previdência do Estado de São Paulo. Relator: Min. Gilmar Ferreira Mendes. Brasilia, 13 de junho de 2006. Disponível em: <http://redir.stf.jus.br/paginadorpub/paginador.jsp?docTP=AC\&doclD=331447>. Acesso em: 20 dez. 2012. ${ }^{87}$ NERY JUNIOR, Nelson, op. cit., p. 46-7.

${ }^{88}$ MARINONI, Luiz Guilherme, op. cit., Coisa julgada [...], p. 31.

${ }^{89}$ NERY JUNIOR, Nelson, op. cit., p. 47.
} 
coisa julgada - ou, como prefere eufemisticamente boa parte da doutrina, que objetive a relativização da coisa julgada". ${ }^{90}$

Por fim, quanto ao aspecto, oportuno transcrever os dizeres de Nery Junior:

O processo civil é instrumento de realização do regime democrático e dos direitos e garantias fundamentais [...]. Desconsiderar a coisa julgada é eufemismo para esconder-se a instalação da ditadura, de esquerda ou de direita, que faria desaparecer a democracia que deve ser respeitada, buscada e praticada pelo processo. [...] A opção é política: o Estado brasileiro é democrático de direito, fundado no respeito à segurança jurídica pela observância da coisa julgada. ${ }^{91}$

Outros doutrinadores optam por um sistema não tão inflexível, tanto para o lado daqueles que defendem a relativização da coisa julgada inconstitucional quanto daqueles que a refutam, utilizando-se do princípio da proporcionalidade.

Acerca da aplicação desse princípio, Cintra, Grinover e Dinamarco destacam que

nenhum valor constitucional é absoluto, devendo todos eles ser sistematicamente interpretados de modo harmonioso e, consequentemente, aplicando-se à coisa julgada o princípio da proporcionalidade, utilizado para o caso de colisão entre princípios constitucionais. ${ }^{92}$

Lenza, citando Karl Larenz, explica que:

O princípio da proporcionalidade ou da razoabilidade, em essência, consubstancia uma pauta de natureza axiológica que emana diretamente das ideias de justiça, equidade, bom senso, prudência, moderação, justa medida, proibição de excesso, direito justo e valores afins; precede e condiciona a positivação jurídica, inclusive no âmbito constitucional; e, ainda, enquanto princípio geral do direito, serve de regra de interpretação para todo o ordenamento jurídico. ${ }^{93}$

Por fim, Lenza ressalta que esse princípio é "extremamente importante especialmente na situação de colisão entre valores constitucionalizados". ${ }^{94}$

Verifica-se, portanto, que na relativização da coisa julgada inconstitucional há verdadeiro conflito entre a segurança jurídica, como expressão da intangibilidade conferida pela

\footnotetext{
${ }^{90}$ MARINONI, Luiz Guilherme; MITIDIERO, Daniel, op. cit., p. 44-5.

${ }^{91}$ NERY JUNIOR, Nelson, op. cit., p. 47.

92 CINTRA, Antonio Carlos de Araújo; DINAMARCO, Cândido Rangel; GRINOVER, Ada Pellegrini, op. cit., p. 329.

${ }_{93}$ LENZA, Pedro, op. cit., p. 97.

${ }^{94}$ Ibidem, p. 98.
} 
coisa julgada, e a necessidade de prolação de decisões judiciais fundamentadas em leis que estejam em consonância com as disposições constitucionais, a fim de se ter postos em prática pelo Poder Judiciário todos os direitos e garantias pautadas pela Constituição da República, fato que determina a aplicação desse princípio.

\section{CONCLUSÃO}

A teoria da relativização da coisa julgada inconstitucional, sem dúvidas, trouxe grandes inovações e reflexões ao estudo do direito processual civil e do direito constitucional, pois defende a flexibilização da intangibilidade, permitindo a reanálise da sentença já acobertada pelo manto da coisa julgada material, ainda que depois do prazo para interposição de ação rescisória, quando o Supremo Tribunal Federal julgar inconstitucional a lei que embasou a decisão proferida.

Para o estudo da teoria, fez-se imprescindível a análise dos efeitos da decisão do Supremo Tribunal Federal em ação direta de inconstitucionalidade e da resolução do Senado Federal suspendendo a execução da lei, em razão da inconstitucionalidade declarada na via difusa pela Suprema Corte.

Nesse ponto, ainda que as divergências doutrinárias sejam grandes e que os argumentos que sustentam a eficácia ex nunc da decisão sejam relevantes, a legislação brasileira que regulamenta a ação direta de inconstitucionalidade optou pelos efeitos ex tunc, com possibilidade de modulação pelo Supremo Tribunal Federal. Igualmente, quanto à resolução do Senado Federal, também se entende que esta possui efeitos ex tunc.

No que pertine aos efeitos retroativos, o grande embate que expressa a controvérsia ocorre nas decisões judiciais já acobertadas pela coisa julgada material, que foram respaldadas na lei declarada inconstitucional, em que a questão se refere à possibilidade de desconstituição da intangibilidade da decisão em razão dos efeitos dados ao julgamento realizado no controle jurisdicional de constitucionalidade, em que a manutenção da segurança jurídica, proveniente da intangibilidade da decisão revela-se aparentemente contrária à certeza de uma decisão em consonância com os preceitos constitucionais.

Os objetivos do trabalho foram atingidos, uma vez que, ao analisar os entendimentos doutrinários acerca da relativização da coisa julgada inconstitucional, verificou-se a necessidade de um sistema jurídico que garanta segurança jurídica, sem, contudo, afastar os demais 
preceitos constitucionais que regem o ordenamento brasileiro, o que permitirá a utilização do instrumento ora estudado em determinadas situações.

$\mathrm{O}$ ordenamento jurídico brasileiro, ao erigir a coisa julgada a direito fundamental e regulamentar este instituto na legislação infraconstitucional, optou pela segurança jurídica, pois as sentenças judiciais tornar-se-ão intangíveis após seu transito em julgado. Logo, o sistema será pautado por relações jurídicas de direito processual estáveis, já que as partes, depois de proferida a decisão e precluso o prazo para interposição de recurso, não poderão rediscutir a matéria objeto da análise jurisdicional, salvo nos casos de ação rescisória, denúncia por violação à convenção americana de direitos humanos, ou de cabimento de querela nullitatis, que são medidas excepcionais, com critérios rigorosos.

É evidente que o ordenamento jurídico deve garantir a intangibilidade de suas decisões, porquanto a vida em sociedade a exige para a manutenção da ordem, sob pena de anarquizar o sistema, acarretando a incredulidade de um Poder do qual se exige seriedade, segurança e justiça.

Deve-se, portanto, preservar e proteger a coisa julgada contra ataques que tentem the mitigar, ou retirar o valor - sendo isso consequência, inclusive, das normas constitucionais -, para preservação do Estado Constitucional e Democrático de Direito. Contudo, não menos importante que a coisa julgada, são os demais direitos e garantias fundamentais, igualmente previstos na Constituição da República.

O mecanismo processual e constitucional brasileiro permite que a própria parte litigante aduza a inconstitucionalidade da lei como meio de defesa, e possibilita, ainda, que o próprio magistrado, ex officio, a declare no julgamento do caso concreto. Ademais, ainda que isso não ocorra durante o trâmite processual, entende-se possível a arguição de inconstitucionalidade da lei no prazo para ação rescisória.

Dessa forma, quando a lei for declarada inconstitucional durante o trâmite processual, ou no prazo para ajuizamento da ação rescisória, constata-se que a utilização da teoria da relativização da coisa julgada inconstitucional não pode ser admitida, porquanto existem meios processuais típicos que permitem a análise do caso concreto sob a ótica constitucional. Não tendo o feito, o direito de alegar a inconstitucionalidade está precluso.

De modo diverso devem ser analisadas as situações onde a lei foi declarada inconstitucional somente após o prazo para ajuizamento da ação rescisória. Ainda que se argumente que a norma já nasceu inconstitucional, podendo ter a parte a alegado, ou o magistrado reconhecido de ofício, a realidade do Judiciário demonstra que a demanda elevada 
de litígios faz com que o julgador, por vezes, não faça o devido controle de constitucionalidade da lei incidentalmente, ou a considere constitucional, ou, também, que a inconstitucionalidade da lei ainda não tenha despertado a atenção dos operadores do direito.

Nessas situações, os argumentos defensivos e contrários à teoria da relativização da coisa julgada inconstitucional não podem ser demasiadamente inflexíveis, uma vez que a situação traduz uma colisão entre dois direitos fundamentais: a intangibilidade da decisão proferida, acobertada pela coisa julgada material, frente ao direito previsto constitucionalmente que não foi observado quando da edição da lei declarada inconstitucional e aplicada ao caso concreto.

Portanto, a ponderação, utilizando-se do princípio da proporcionalidade ou razoabilidade, é a melhor solução para o problema posto em questão. Somente após a análise criteriosa e verificando a impossibilidade de convivência harmônica de dois direitos fundamentais é que algum destes poderá ser mitigado minimamente, para que os preceitos constitucionais sejam atendidos.

Assim, ainda que a possibilidade de desconsiderar a coisa julgada material por um meio atípico, que é a relativização da coisa julgada inconstitucional, cause o temor da possibilidade de extermínio da ordem constitucional democrática, também é temível permitir-se que decisões contrárias à própria constituição sejam acobertadas indistintamente pela intangibilidade. Isso sim seria passível de completa insegurança jurídica.

Dessa forma, caso a declaração de inconstitucionalidade pelo Supremo Tribunal Federal se dê no curso do processo ou dentro do prazo da rescisória, e a parte prejudicada deixa de atacar a decisão proferida com base na lei declarada inconstitucional, a relativização da coisa julgada não pode ser aceita.

Entretanto, se a declaração de inconstitucionalidade da lei sobrevier ao término do prazo para ajuizamento da ação rescisória, a hostilização da coisa julgada inconstitucional, por absoluta ausência de oportunidade para a parte alegar tal dissonância com a Constituição da República, pode ser aceita, para adequar a decisão ao texto da norma constitucional, quando essa situação, em um juízo de ponderação, seja a mais adequada e menos gravosa à solução do caso concreto.

É certo, porém, que o presente estudo, apesar de colaborar, não pacifica o entendimento quanto ao tema, razão pela qual é necessário um maior aprofundamento, com o consequente aprimoramento da tese, devendo ser incitado pelos doutrinadores e institutos de 
estudos sobre o direito processual civil e o direito constitucional, com o que se estará colaborando para a defesa da Constituição da República.

\section{REFERÊNCIAS}

ARAÚJO, Marcelo Cunha de. Coisa julgada inconstitucional: hipóteses de flexibilização e procedimentos para Impugnação. Rio de Janeiro: Lumen Juris, 2007.

BASTOS, Celso Ribeiro; MARTINS, Ives Gandra. Comentários à Constituição do Brasil: promulgada em 5 de outubro de 1988. vol. 2. São Paulo: Saraiva, 1989.

BRASIL. Código de Processo Civil. Brasília: Congresso Nacional, 1973. Disponível em: <http://www.planalto.gov.br/ccivil_03/Leis/L5869.htm>. Acesso em: 20 dez. 2012.

Constituição da República Federativa do Brasil. Brasília: Senado Federal, 1988. Disponível em: <http://www.planalto.gov.br/ccivil_03/Constituicao/Constituicao.htm>. Acesso em: 20 dez. 2012.

Lei de Introdução às Normas do Direito Brasileiro. Rio de Janeiro: Congresso Nacional, 1942. Disponível em: <http://www.planalto.gov.br/ccivil_03/decreto-

lei/Del4657compilado.htm>. Acesso em: 20 dez. 2012.

Supremo Tribunal Federal. Agravo regimental no recurso extraordinário $n^{\circ} 217.141$ 5/SP. Neusa Gomes Delgado e Instituto de Previdência do Estado de São Paulo. Relator: Min. Gilmar Ferreira Mendes. Brasilia, 13 de junho de 2006. Disponível em:

<http://redir.stf.jus.br/paginadorpub/paginador.jsp?docTP=AC\&docID=331447>. Acesso em: 20 dez. 2012.

BULOS, Uadi Lammêgo. Curso de direito constitucional. 2. ed. rev. e atual. São Paulo: Saraiva, 2008.

CÂMARA, Alexandre de Freitas. Lições de Direito Processual Civil. 20. ed. Rio de Janeiro: Lumen Juris, 2010.

CINTRA, Antonio Carlos de Araújo; DINAMARCO, Cândido Rangel; GRINOVER, Ada Pellegrini. Teoria Geral do Processo. 25. ed. São Paulo: Malheiros, 2009.

DELGADO, José Augusto. Efeitos da coisa julgada e os princípios constitucionais. São Paulo: II Seminário de Direito Ambiental Imobiliário, 1999. Disponível em:

<http://www.pge.sp.gov.br/centrodeestudos/bibliotecavirtual/ambiental3/painel4.htm>. Acesso em: 20 dez. 2012.

DIAS, Francisco Barros. Breve análise sobre a coisa julgada inconstitucional. Disponível em: <http://www.jfrn.jus.br/institucional/biblioteca/doutrina/doutrina129.doc>. Acesso em: 20 dez. 2012. 
DIDIER JUNIOR, Fredie; BRAGA, Paula Sarno; OLIVEIRA, Rafael. Curso de Direito Processual Civil. 3. ed. Bahia: Juspodivm, 2008.

FERREIRA, Olavo A. V. Alves. Controle de Constitucionalidade e seus efeitos. São Paulo: Método, 2005.

GRECO, Leonardo. Eficácia da declaração erga omnes de constitucionalidade ou inconstitucionalidade em relação à coisa julgada anterior. Disponível em: < http://www.mundojuridico.adv.br/cgi-bin/upload/texto167.rtf >. Acesso em: 20 dez. 2012.

GRINOVER, Ada Pellegrini. O processo: estudos e pareceres. São Paulo: Perfil, 2005.

LENZA, Pedro. Direito Constitucional Esquematizado. 13. ed. rev., atual. e amp. São Paulo: Saraiva, 2009.

MARINONI, Luiz Guilherme. Coisa Julgada Inconstitucional. 2. ed. rev. e atual. São Paulo: Revista dos Tribunais, 2010.

. Sobre a chamada "relativização" da coisa julgada material. Disponível em:

<http://www.abdpc.org.br/abdpc/artigos/Luiz\%20G\%20Marinoni\%2814\%29\%20-formatado.pdf>. Acesso em: 20 dez. 2012.

; ARENHART, Sérgio Cruz. Processo de Conhecimento. 7. ed. rev. e atual. São Paulo: Revista dos Tribunais, 2008.

; MITIDIERO, Daniel. O projeto do CPC: crítica e propostas. São Paulo: Revista dos Tribunais, 2010.

MIRANDA, Francisco Cavalcanti Pontes de. Comentários à Constituição de 1967. Tomo III. São Paulo: Revista dos Tribunais, 1967.

, Francisco Cavalcanti Pontes de. Comentários ao Código de Processo Civil. Atualização legislativa de Sérgio Bermudes. vol. V. 3. ed. Rio de Janeiro: Forense, 1997.

, Francisco Cavalcanti Pontes de. Comentários ao Código de Processo Civil. vol. VI., 1. ed. São Paulo: Forense, 1975.

NEGRÃO, Theotonio; GOUVÊA, José Roberto Ferreira. Código de Processo Civil e legislação processual em vigor. 40. ed. São Paulo: Saraiva, 2008.

NERY JUNIOR, Nelson. Princípios do processo civil na Constituição Federal. 8. ed. rev., ampl. e atual. São Paulo: Revista dos Tribunais, 2004.

NEVES, Daniel Amorim Assumpção. Manual de direito processual civil. 4. ed. rev., atual. e ampl. São Paulo: Método, 2012.

PAULO, Vicente, ALEXANDRINO, Marcelo. Controle de constitucionalidade. 8. ed. São Paulo: Método, 2009. 
SILVA, Beclaute Oliveira. Coisa julgada baseada em lei inconstitucional (?) Considerações acerca da teoria Pontiana. Disponível em: <http: / /www.procuradoria.al.gov.br/centro-deestudos/artigos/COISA\%20JULGADA\%20INCONSTITUCIONAL.pdf>. Acesso em: 20 dez. 2012.

SILVA, José Afonso da. Comentário contextual à Constituição. 2. ed. São Paulo: Malheiros, 2006. 2003.

. Curso de direito constitucional positivo. 22. ed., rev. e atual. São Paulo: Malheiros,

WAMBIER, Teresa Arruda Alvim, MEDINA, José Miguel Garcia. O dogma da coisa julgada. São Paulo: RT, 2003.

Recebido em: 20.12 .2012

Aprovado em: 13.03.2013 